\title{
Un ejercicio de historia regional comparada: coacción y mercado de trabajo.Tucumán y Mendoza en el horizonte latinoamericano (segunda mitad del siglo $\mathrm{XIX}$ )
}

\author{
Daniel Campi \\ Conicet-Universidad Nacional de Tucumán \\ Rodolfo Richard-Jorba \\ Conicet-Universidad Nacional de Cuyo, Mendoza
}

Las provincias argentinas de Tucumán, en el norte, y Mendoza, en el centro-oeste, centraban su actividad económica a comienzos de la década de 1850 en el intercambio mercantil con el "espacio económico peruano",' la primera, y con el mercado chileno, la segunda, aunque variadas producciones propias atendían demandas en ámbitos regionales amplios.

A partir de la década de 1870 , diversos factores determinaron transformaciones sustanciales en sus dos espacios productivos. El avance del poder central argentino, la integración física del territorio con los ferrocarriles y el ocaso de los vínculos económicos con los antiguos mercados motivaron a las élites locales a reorientar las economías provinciales. Se avanzó, entonces, hacia la producción en gran escala de azúcar y de vino respectivamente, a fin de atender un mercado interno en formación, que se ampliaba espacial y demográficamente. Surgirían así, las primeras "economías regionales" de la Argentina moderna, complementarias del estratégico espacio central pampeano. ${ }^{2}$

* Trabalho apresentado no IV Congresso Brasileiro de História Econômica, São Paulo, setembro de 2001.

Carlos Sempat Assadourian denominó "espacio peruano" al sistema de articulaciones económicas que - con centro en la minería potosina - conectaba en el período colonial a diversos mercados y regiones del área surandina. Assadourian, Carlos Sempat, El Sistema de la Economía Colonial. El Mercado Interior: Regiones y espacio económico, México: Nueva Imagen, 1983. Antonio Mitre lo denominó, a su vez, "espacio económico surandino". Mitre, Antonio, El Monedero de los Andes: Región económica y moneda boliviana en el siglo XIX, La Paz: Hisbol, 1987.

Cf., Campi, Daniel y Richard Jorba, Rodolfo,"Las tendencias a la formación del - 
En ese marco, la necesidad de contar con una fluida oferta de mano de obra, crónicamente escasa, condujo a la adopción de diversas políticas. Desde la coacción extraeconómica en sus variadas formas, hasta los crecientes incentivos monetarios, estas políticas motivaron, en el caso de Tucumán, la transformación en asalariados de importantes núcleos humanos insertos en economías de subsistencia y, también, la succión de fuertes contingentes de pobladores de provincias vecinas. Un proceso similar aconteció en Mendoza, aunque esta provincia se caracterizó también por atraer un considerable aporte de inmigrantes de países europeos. ${ }^{3}$ En este trabajo se pretende ensayar una primera aproximación comparativa sobre la singular conformación en ambos espacios de modernos mercados laborales bajo la vigencia legal de normativas sociolaborales coactivas. Se analizará el comportamiento de los diversos actores sociales, el papel jugado por los Estados provinciales y el Estado nacional y las causas que determinaron la extinción de la coacción laboral en las décadas de 1880 y 1890.

\section{el régimen de la papeleta de conchabo y del peonaje por deudas}

La papeleta de conchabo y la retención por deudas signaron en Tucumán y Mendoza - y en todo el territorio argentino- las relaciones laborales en la mayor parte del siglo XIX, y bajo la vigencia de tales instituciones se desarrolló el mercado de trabajo que acompañó la expansión de las agroindustrias de la caña de azúcar y de la vid. La papeleta de conchabo, que derivaba de las genéricamente conocidas leyes contra la vagancia, era un documento emitido por una autoridad competente (policía o juez de paz) que certificaba que determinado individuo estaba bajo relación de dependencia laboral con un patrón. Para quienes no poseían oficio, profesión, renta, sueldo, ocupación o medio lícito con que vivir era condición

mercado interno Las producciones regionales extrapampeanas", en Marta Bonaudo (Coord.), Liberalismo, Estado y Orden Burgués, 1852-1880, tomo 4 de la obra Nueva Historia Argentina (Buenos Aires: Sudamericana. 1999).

Los dos primeros censos nacionales, de 1869 y 1895 , registraron 108.953 y 215.742 habitantes para Tucumán, respectivamente; y 65.413 y 116.136 para Mendoza.

El articulo 47 de) Reglamento General de Policía de la Provincia de Tucumán de 1877. Mendoza se regia por el articulo 58 de] Reglamento de Policía (Ley del 18.3.1828), ratificado en 1845 y 1855.Con ligeras variantes, esta era la caracterización del sector de la población a que estaban especialmente dirigidas las normativas 
de su existencia legal, ya que, sin tal documento, eran considerados vagos (o sospechosos de serlo) y pasibles de ser perseguidos y castigados como tales.

Junto a la indigencia, de la que se desprendía la sospecha de "vagancia", había una serie de conductas que se tipificaban con esta calificación: todas las que amenazaran los derechos de propiedad, el orden y la moral instituidas por los sectores dominantes, incluyendo la afición al juego, al alcohol, la mendicidad, el vagabundaje, etc. Los castigos y reprensiones aplicados a los incriminados como vagos eran variados, en función de las peculiaridades locales y los intereses de particulares y del Estado puestos enjuego, siendo los trabajos públicos forzados y el servicio de armas en la frontera los más frecuentes.

En la génesis de este tipo de normativas durante la Colonia no fueron los requerimientos productivos los que primaron, pero cuando en la segunda mitad del siglo XIX la demanda de mano de obra cobró capital importancia, esta legislación socio-laboral fue revitalizada para la captación y retención de trabajadores, sirviendo de un modo complejo a la formación de mercados de trabajo indispensables para satisfacer las necesidades de la expansión económica que aconteció en gran parte del territorio nacional.

En las décadas de 1820,1830 y 1840 , tanto en Mendoza como en Tucumán se reafirmó la sujeción de los trabajadores a los patrones. A través de leyes, decretos o edictos policiales se establecían penalidades a los indigentes que carecían de papeleta de conchabo y a quienes contrataran peones sin que éstos demostraran con una papeleta de desconchabo estar libres de deudas y haber finalizado su relación laboral anterior. Los fundamentos de estas ordenanzas eran siempre disciplinadores y moralizantes, apuntando a erradicar los vicios, la holgazanería y la inmoralidad, con la pretensión de modificar hábitos, conductas y sistemas de valores de los sectores populares. Para los grupos dominantes se trataba de uno de los requisitos de la modernización de la sociedad y, desde esta perspectiva, los aspectos económicos, políticos y culturales de la cuestión se integraban, pues no se pueden disociar los esfuerzos por transformar los hábitos laborales de los que pretendían anular las manifestaciones culturales y políticas autónomas de las clases subalternas.

Obviamente, tanto la variada gama de mecanismos e instrumentos

sobre conchabo contenidas en reglamentos de policía, códigos rurales o reglamentos de estancias de las provincias hoy argentinas durante gran parte del siglo XIX. 
de represión social y "moralización", como el control del esparcimiento popular y los esfuerzos por imponer valores y pautas culturales de las clases dominantes (definición de los derechos de propiedad, nociones de lo legal e ilegal, del trabajo, del ocio, del tiempo, de la diversión, etc.) deben entenderse como partes de una misma empresa "civilizadora" de los sectores populares, que fue encarada en toda América Latina en el siglo XIX. Por lo tanto, más allá de los rasgos particulares que adquirieron en Tucumán y Mendoza la coerción laboral y el peonaje por deudas, su examen debe realizarse en perspectiva con el debate que sobre la cuestión se desarrolló en la historiografía latinoamericana.

\section{la cuestión del peonaje en la historiografía latinoamericana}

A partir de la Independencia se fue conformando en Hispanoamérica un pensamiento crítico sobre diversos aspectos de la realidad, rémoras del pasado colonial que contradecían las aspiraciones de progreso económico y social compartidas por las élites criollas. La gran propiedad rural, la tiranía política, los mayorazgos y otros privilegios de grupos minoritarios se consideraban incrustaciones de tipo feudal que debían removerse para poner a las jóvenes naciones a la altura de los tiempos. Sin embargo, como bien ha señaladoJosé Carlos Chiaramonte, el calificativo de "feudal" a una institución particular no implicaba la caracterización global de la sociedad o de sus instituciones fundamentales. Se trataba de la impugnación a situaciones que se consideraban incongruentes, generalmente desde una perspectiva política, en el marco de estructuras socioeconómicas sobre cuya evolución predominaban visiones optimistas.

En la segunda mitad del siglo XIX se hicieron frecuentes los cuestionamientos a la institución del peonaje y a otras formas de coacción laboral, presentados como arcaísmos de naturaleza semiservil y hasta esclavista tanto por pensadores políticamente radicales como desde el liberalismo moderado. En el primer tomo de El Capital, refiriéndose a las condiciones que hacían del trabajador asalariado un serjurídicamente libre, Marx afirmaba que

Cf. Chiaramonte, José Carlos, "Génesis del 'diagnóstico' feudal en la historia hispanoamericana", en José Carlos Chiaramonte, Formas de Sociedad y Economía en Hispanoamérica, México: Enlace-Grijalbo, 1983. 
"[...] En diferentes países, en especial en México, la esclavitud se encuentra disimulada bajo una forma que lleva el nombre de peonaje [...] Por medio de anticipos deducibles del trabajo y que se trasmiten de una generación a otra, no sólo el trabajador aislado, sino también su familia, se convierten en propiedad de otras personas y de sus familias $[\ldots]^{\prime \prime}$

En el tránsito del siglo XIX al XX, esa imagen estaba muy generalizada y era compartida, por ejemplo, tanto por Karl Kaerger (agrónomo alemán que escribió una importante obra sobre la agricultura y la colonización en América Latina) ${ }^{7}$ como por Genaro Raigosa (defensor de la política agraria de Porfirio Díaz), quienes consideraban a los peones mexicanos endeudados como esclavos de hecho. Pero esta idea "pesimista" sobre las consecuencias de la práctica del endeudamiento sobre la condición de los trabajadores (que, en teoría, eran hombresjurídicamente libres para el ideario republicano) no fue el fundamento de los primeros diagnósticos formulados desde la historiografía que atribuían a las sociedades latinoamericanas una naturaleza "feudal". Fueron los fenómenos del caudillismo y de la anarquía política los que indujeron a apelar a dicha categoría para explicarlos, toda vez que la concepción predominante del feudalismo daba prioridad a la dispersión del poder político en beneficio de los grandes propietarios rurales.'

Con la difusión del marxismo, la caracterización "feudal" se fundamentaba en la naturaleza de las relaciones conformadas en torno al trabajo,"[...] de manera que si se lograba demostrar la índole servil de esas formas de trabajo se infería de inmediato el feudalismo [...]", ${ }^{10}$ como lo harían Luis Chávez Orozco y Rodolfo Puiggrós para los casos mexicano y argentino, respectivamente. ${ }^{12}$ El concepto tuvo una amplia irradiación y fue reproducido en la historiografía inclusive desde

Marx, Carlos, El Capital, Buenos Aires: Cartago, 1989, tomo I,p. 175 (cursivas en el original).

Kaerger, Karl, Landwirtschaft und Kolonisation in Spanischen Amerika, Leizpig, 1901. Cf. González Navarro, Moisés, "Kaerger: peonaje, esclavitud y cuasiesclavitud en México", Historia Mexicana, VoL. XXXVI, n 3,1987, pp. 529-536.

Chiaramonte, José Carlos, "Génesis op. cit., pp. 58-60.

Ibíd,p. 20 .

"Ibíd, pp. 84-89. El punto requiere una aclaración imprescindible. Se trataba del marxismo de cuño estalinista difundido desde la Unión Soviética, que establecía un curso histórico eurocéntrico para todas las sociedades y en el cual la "etapa" feudal era ineluctable. 
perspectivas no necesariamente marxistas, pese a que, a partir de la década de 1960, comenzaron a difundirse una serie de investigaciones (fundamentalmente sobre el peonaje y la hacienda en México) que proponían conclusiones diferentes sobre este punto.'

Aunque sin duda esa interpretación encontraba un argumento de peso en las lamentables condiciones de existencia de los trabajadores, sometidos en algunas regiones a niveles de explotación y sufrimiento extraordinarios, como en Yucatán, ${ }^{13}$ se constituyó en una especie de estereotipo sobre el peonaje, aplicado a toda la geografía latinoamericana. Sin que implique una valoración negativa sobre obras en general meritorias, no está de más hacer referencia a una serie juicios que, en esa línea, han elaborado algunos historiadores. Por ejemplo, según Claude Morín, en México

"El endeudamiento consagra la sujeción personal de los trabajadores a la tierra y, por medio de ella, a los terratenientes. La obligación de liquidar la deuda, condiciónjurídica, es el medio por el cual el propietario arrebata el plustrabajo al productor. Bajo la máscara de relaciones salariales se ocultan unas relaciones casi feudales."

La importancia del debate sobre el peonaje en México determina que las referencias al mismo predominen frente a las discusiones generadas en torno a otros casos latinoamericanos. Como no pretendemos esbozar un balance exhaustivo sobre el debate en toda la historiografía latinoamericana, creemos que se trata de una opción válida.

13 Cf. García Quintanilla, Alejandra,"Producción de henequén, producción de hombres (Yucatán, 1850-1915)", en Mario Cerutti (coordinador),El Siglo XlX en México. Cinco procesos regionales: Morelos, Monterrey,Yucatán,Jalisco y Puebla, México: Claves Latinoamericanas, 1985.

Morín, Claude, Michoacán en la Nueva España del siglo XVIII. Crecimiento y desigualdad en una economía colonial, México: FCE, 1979, p. 268. Uno de los más entusiastas sostenedores de una visión "pesimista" sobre el peonaje en América Latina es Ruggiero Romano, para quien las prácticas del crédito y del endeudamiento, la tienda de raya, la diferencia "sutil" que —en los hechos— habría existido entre trabajo "compulsivo" y trabajo "libre", y la presencia de formas compulsivas "indirectas", tornan ilusorias los márgenes de libertad que habrían gozado indígenas y peones en Hispanoamérica. En ello, y en una de sus directas consecuencias (la transformación de los peones en virtuales siervos y la primacía de los intereses privados de los hacendados sobre los del Estado), funda su tesis sobre el "feudalismo americano" «El feudalismo americano», en Romano, Ruggiero, Consideraciones, Lima: Fomciencias-Instituto Italiano de Cultura, 1992; "Trabajo compulsivo y trabajo libre en Nueva España (siglos XVI-XVIII)", en Blanchard, Francis et all., El Trabajo en la Historia, Salamanca: Ediciones de la Universidad de Salamanca, 1996. 
Esa misma idea de que "detrás" de la relación bajo la forma salarial se estaría en presencia de relaciones sociales precapitalistas ha sido desarrollada por Andrés Guerrero para el caso ecuatoriano de fines del siglo XIX y principios del XX. En Ecuador, según este autor,

"En apariencia, la relación entre los sembradores y los peones con el hacendado se presenta como una relación monetaria que, en cierta medida se asemeja a la forma de trabajo asalariada: el pago por la huerta de cacao, los adelantos y los jornales son, efectivamente, determinadas formas de relación monetaria. No obstante sería un error pensar que es gracias a una forma de tipo salarial (compra y venta en el mercado de la fuerza de trabajo) que se efectúa la introducción del trabajador directo en el proceso de producción."'s Sin embargo, como anticipamos unas líneas más arriba, desde la década de 1960 comenzaron a difundirse una serie de investigaciones que ponían en cuestión la imagen del peonaje por deudas como mecanismo o institución que en toda América Latina sometía a los trabajadores a formas de semiesclavitud o semiservidumbre. La obra de Gibson sobre los aztecas bajo el dominio español marca al respecto una inflexión en la historiografía latinoamericana, aunque ya en la década de 1940 Silvio Zavala había presentado una visión más matizada y compleja del peonaje en el México colonial.'

En el trabajo citado, Gibson proponía que los niveles de endeudamiento de los trabajadores podían ser también considerados como

15 Guerrero, Andrés, "Ensayo sobre la acumulación originaria en Ecuador: haciendas, cacaoteros, banqueros exportadores y comerciantes de Guayaquil, 1890-1910", en Enrique Florescano, (Coord.), Orígenes y Desarrollo de la Burguesía en América Latina, 1700-1955, México: Nueva Imagen, 1985, p. 403.

${ }^{16}$ Decía Zavala en un trabajo publicado por primera vez en 1944:"[...] Jurídicamente los gañanes son hombres libres que no proceden en línea directa de los esclavos de la conquista ni de los vasallos de la encomienda [...] En la hacienda, el indio es un trabajador libre atraído por medio de un alquiler voluntario, conservándose esta apariencia jurídica aun en el caso de que el hacendado ejerza alguna presión económica o de otro orden. El amo debe pagar un salario al gañán a cambio del trabajo; por eso hay libros de cuentas con partidas de debe y haber. La libertad de movimiento del gañán se ve comprometida por los anticipos dejornal y los tributos y obvenciones que el hacendado paga por él. Esta dependencia es de orden civil y redimible en dinero [...] El sonsaque y las fugas, de una parte, y la restricción del movimiento, de otra, constituyen los polos dentro de los cuales se desarrolla el problema [...]" (Zavala, Silvio, "Orígenes coloniales del peonaje en México", en Silvio Zabala, Estudios Acerca de la Historia del Trabajo en México, México: El Colegio de México, 1988, p. 56. 
indicadores de la "capacidad de regateo" de los mismos. Apelando a informes de funcionarios y observadores de la Colonia, afirmaba:

"[...] Por "costumbre antigua", los indios solicitaban anticipos de 40 a 80 pesos, y si un patrón se negaba a subir la oferta a más de cinco pesos, el indio desertaba y se trasladaba a otra hacienda donde las condiciones fueran más atractivas. En este caso, es más importante la interpretación convencional del trabajo por deudas, ya que supone la relativa libertad existente entre los trabajadores, cuyo objetivo no era escapar sino aumentar la deuda [... "17

En 1979, a su vez, Arnold Bauer hacía notar, en un provocativo artículo, ${ }^{18}$ que la transición de formas no capitalistas de agricultura a formas capitalistas se dio en América Latina con diferentes ritmos y bajo una gran variedad de circunstancias, y que, en ese proceso, la historia de los trabajadores fue una historia de opresión e injusticias, pero también de "elecciones" y "ajustes". Según Bauer, la capacidad de los terratenientes para ejercer discrecionalmente el poder no puede generalizarse; consecuentemente, tampoco sus posibilidades de mantener inmovilizada a la mano de obra y de reducir al mínimo sus ingresos. Como contrapartida, propone revisar la visión del endeudamiento como instrumento de exacción sobre las peonadas, para valorarlo como una forma de crédito, como "un anticipo en dinero o mercancías contra la promesa de trabajo", de la que los trabajadores sabían sacar con astucia, muy frecuentemente, importantes ventajas. ${ }^{19}$

En México el debate se integró a las discusiones sobre la hacienda, sintetizadas en 1983 por Van Young en la Latin American Research Review. ${ }^{20}$ Haciendo referencia a las posturas más "optimistas" de los cuestionadores

${ }^{17}$ Gibson, Charles, op. cit., p. 261: "Un trabajador indio inclinado a abandonar su hacienda podía encontrar la ocasión de hacerlo a pesar de sus deudas, así como cualquier indio podía evadir su deuda de tributo a un pueblo o su deuda privada a cualquier acreedor", Ibíd., p. 259).

18 Bauer, Arnold J.: "Rural Workers in Spanish America: Problems of Peonage and Opression", Hispanic American Historical Review, 59 (1), 1979. Ver tambiém em la crítica a este artículo -de Brian Loveman-y la respuesta de Bauer, en HAHR, 59 (3), 1979).

19 Ibíd, p. 36.

${ }^{20}$ Van Young, Eric, "Mexican Rural History Since Chevalier: The historiography of de Colonial Hacienda", Latin American Research Review, Vol. 18, n 3,1983. Publicado en castellano, "Historia rural mexicana desde Chevalier: historiografía de la hacienda colonial», en Eric Van Young, La Crisis del Orden Colonial: Estructura agraria $y$ rebeliones populares de la Nueva España, México: Alianza Ed., 1992. 
de las imágenes acuñadas por la historiografía tradicional, según este autor:

"[...] Quizá el punto en el que los revisionistas han ido más lejos en su intento de bajar del pedestal a la sabiduría convencional sobre la vida en el campo antes de 1910 es el del servilismo y la permanencia de la fuerza de trabajo en las propiedades rurales (Cros, 1979, Bauer, 1979). Como pequeño anticipo del próximo debate sobre la mano de obra rural, diremos que estas visiones color de rosa del trabajo en el campo a veces superan nuestra credulidad. Por ejemplo, nos resistimos a despejar en nuestra mente la negra imagen de la tienda de raya como una institución explotadora, ante los intentos de rehabilitarla planteándola como una especie de tienda campesina relativamente benigna. Sin embargo, parece ser que los trabajos recientes sobre este tema han puesto bastante claro que los trabajadores rurales tenían una relación más compleja con las propiedades rurales y menos parecido con los siervos europeos de lo que en otra época se había pensado [... $]^{\prime 21}$

El debate tiene, sin lugar a dudas, una gran carga política, relacionada tanto con tradiciones ideológicas como con las diferentes percepciones de los historiadores sobre la realidad social del agro latinoamericano de nuestros días. No obstante ello, puede afirmarse que la visión "pesimista" sobre peonaje por deudas y de otros mecanismos coercitivos ha quedado definitivamente erosionada.

"[...] Existe la posibilidad - continúa Van Young- de que la deuda misma fuera un indicador de éxito de los trabajadores rurales al lograr que aumentaran sus salarios, de que el aumento de la deuda fuera muestra de un poder de negociación, idea que ha sido sugerida por varios investigadores (Gibson, 1964; Brading, 1978). Lo inverso habría sido que cuando disminuía el poder de negociación del trabajador, ya sea debido a una oferta excesiva de mano de obra o a un debilitamiento de la posición de las grandes propiedades en el mercado, el nivel de endeudamiento tendería a bajar [... "2z

Van Young, «Historia rural mexicana...", op. cit., pp. 148-149.

Ibíd, p. 153. Un balance historiográfico sobre la hacienda colonial mexicana más reciente coincide con estas propuestas de Van Young:"[...] La retención de trabajadores del campo por deudas [...] refleja no tanto la debilidad de esta relación sino la fuerza de los interesados [...] Con el crecimiento demográfico y la consiguiente ampliación del mercado laboral se fue invirtiendo esta situación en las postrimerías del siglo XVIII y el endeudamiento disminuyó en forma considerable [...]" Langue, 
Similares son las conclusiones a las que arriba Michael Gonzáles en sus investigaciones sobre las plantaciones azucareras del norte peruano de fines del siglo XIX y primeras décadas del XX, donde la institución del "enganche" para la captación de trabajadores serranos adquirió un gran desarrollo:

"[...] La interpretación tradicional de contratación de la mano de obra enfatiza la importancia de la coerción y del peonaje de deuda. La evidencia del norte de Perú muestra que la coerción, relativamente, tenía poca importancia y que el peonaje de deuda era ineficiente y a menudo antiproductivo. Los mismos trabajadores ayudaron a socavar el peonaje de deuda al escapar en grandes números, luego de haber acumulado grandes deudas, a veces en más de una plantación $[\ldots]^{23}$

Quizás sea necesario advertir que, en este debate tan resumidamente reseñado, no se pretende invalidar, ni mucho menos, la presencia de la coerción en la captación y retención de trabajadores, con toda su carga de violencia y explotación; ni implicar, como es obvio, la reivindicación de aquella tradición historiográfica inspirada en el hispanismo católico, que - en su empeño por rebatir la "leyenda negra" americana- exaltaba la importancia de los "principios cristianos" de la legislación de Indias frente a las prácticas de la vida social. ${ }^{24}$ De lo que se trata aqui es de definir los verdaderos alcances de la coacción que se ejerció, tanto en el período colonial como en el independiente, en contextos, situaciones y coyunturas muy variados. La presencia de los mecanismos del mercado fue, en este sentido, indudable, y éstos adquirieron singular importancia cuando la oferta de trabajadores fue insuficiente, afectando la eficiencia y los costos de los mecanismos coercitivos. Como reflexiona Van Young, las tendencias al aumento de salarios bajo el imperio de normativas coercitivas implican situaciones de mercado competitivas, en las cuales necesariamente debe haber existido "cierto grado de movilidad física de los

Frédérique, "La historiografía mexicanista y la hacienda colonial. Balances y reconsideraciones", Secuencia, n ${ }^{\circ}$ 2, México, 1998.

Gonzáles, Michael, "El control de los hacendados y la resistencia de los trabajadores en el Norte del Perú: 1880-1921". HISLA, XIII-XIV, Lima, 1989, p. 48. Cf, también, Plantation Agriculture and Social Control in Northern Perú, 1875-1933,Amún: University of Texas Press, 1985.

* Rómulo Carbia fue uno los exponentes argentinos más destacados de esta corriente Cf. Carbia, Rómulo, Historia de la Leyenda Negra Hispano-Atnericana, Buenos Aires: Ediciones Orientación Española, 1943. 
vendedores de mano de obra". ${ }^{25}$ En esas circunstancias, la demanda insatisfecha de mano de obra - y la competencia que se planteaba por ella entre empresas, haciendas, contratistas o "enganchadores"- habría permitido a los trabajadores lograr ciertas ventajas y hacer más eficaces las distintas estrategias de resistencia que desplegaban ante las clases dominantes. Una de las conclusiones a la que fue posible arribar a partir de estos desarrollos, es obvia: permitió repensar la historia del mundo de trabajo en América Latina, revalorizando a los peones y gañanes como actores con capacidad para modelar su propia historia.

\section{las imágenes del trabajador rural en el área rioplatense en los siglos XVIII y XIX}

No son escasos los estudios, en la historiografía argentina sobre el siglo XIX, referidos a la condición del trabajador rural. Sin embargo, el enfoque que se ha privilegiado tradicionalmente ha sido el del análisis de las normativas laborales, en particular de la legislación contra la vagancia y el sistema de la papeleta de conchabo, haciendo caso omiso de la documentación que da cuenta de las estrategias de los actores frente a los mismos.

Aunque en muchos de estos trabajos se recogen numerosas referencias sobre la conducta refractaria de las peonadas frente a las normas que se intentaba imponerles con tal tipo de legislación, el interés de los historiadores sólo recientemente se ha dirigido hacia esta cuestión. Hasta no hace muchos años, lo que ha dominado la preocupación de los investigadores es la descripción y análisis de los instrumentos de poder de los hacendados, en particular de la poderosa oligarquía latifundista del litoral, siempre asociada — de una forma u otra- al poder políticomilitar criollo.

La imagen sobre el trabajador rural del área rioplatense se derivaba en esta visión dominante- de la definición de la naturaleza del poder de la oligarquía terrateniente, resumida en la tesis del "feudalismo ganadero". ${ }^{26}$ Según ésta, esa clase, apoyada en la milicia y en los jueces de paz, habría detentado un poder casi omnímodo en las áreas rurales,

Van Young, op. cit., p. 153.

Una crítica a esta visión en el artículo de Ricardo Salvatore, "Reclutamiento militar, disciplinamiento y proletarización en la era de Rosas", Boletín del Instituto de Historia Argentina y Americana Dr. Emilio Ravignani, $\mathrm{n}^{\circ}$ 5, 1992, pp. 28-29. 
reduciendo a las peonadas a un estado asimilable a la servidumbre, en tanto mano de obra cautiva en virtud de la coerción extraeconómica.

El efecto de esta imagen fue dificultar las indagaciones sobre cuestiones que resultan claves en el momento de definir la relación de los terratenientes (y propietarios rurales en general) con los trabajadores. Entre ellas, todo lo concerniente al funcionamiento del mercado de trabajo: la movilidad de la mano de obra, la composición y evolución de los salarios, la articulación o conflicto entre coerción e incentivos monetarios en la captación y retención de la fuerza de trabajo, para citar algunas. Por otro lado, tal imagen agregaba una alta dosis de confusión conceptual, utilizando con gran liberalidad ciertas categorías de precisos significados para la historia europea, como "feudalismo" y "servidumbre", las que, con su potente carga ideológica, no ayudaban a clarificar la naturaleza de la formación histórico-social rioplatense. Nada más elocuente, al respecto, que la introducción a un estudio sobre la represión a la vagancia, la papeleta de conchabo y las levas que hacía O. Carracedo en 1958:

"[...] Después de la Revolución de Mayo, hasta una época muy posterior a la constitución de 1853, subsistieron las relaciones de carácter feudal propias de la Colonia. Las luchas que de modo tan dramático desgarraron al país durante un largo período, al empobrecerlo, hicieron aún más rigurosa la sujeción en que se encontraban los aborígenes y los hombres de trabajo [... "27

En la misma línea interpretativa, a comienzos de la década de 1980 Ricardo Rodríguez Molas asimilaba asalariados y siervos, analizando el código rural bonaerense de 1865 :

"[...] El peón está obligado a realizar toda clase de tareas fuera de las horas establecidas "si es requerido al efecto por el patrón". Para los asalariados, el libre tránsito por el territorio de Buenos Aires está condicionado con escrupulosa meticulosidad. El siervo, para la mentalidad de las autoridades y estancieros feudales, debe permanecer bajo el dominio del propietario de la tierra $[, \ldots]^{28}$

Más allá del mérito que podrían tener estos trabajos considerando

Carracedo, Orlando,"Vagancia,conchabo y levas en la legislación del Litoral", Anuario, Instituto de Investigaciones Históricas, Facultad de Humanidades y Artes, Universidad Nacional de Rosario, 1958, Año III, nº 3.

${ }^{28}$ Rodríguez Molas, Ricardo, Historia Social del Gaucho, Buenos Aires, CEAL: 1982, p. 213 (las cursivas nos pertenecen). 
el contexto historiográfico en el que fueron elaborados, han sido seleccionados por recoger la visión estereotípica sobre el peón rural que privilegiaba como variables determinantes de sus valoraciones y análisis los instrumentos legales y el discurso de los sectores dominantes, desatendiendo el protagonismo de otros actores sociales, el de las peonadas. Sin embargo - como se ha dicho-en los últimos años esta visión ha sido sometida una fuerte revisión. En la polémica que desarrollaron en 1987 Carlos Mayo, Juan Carlos Garavaglia,Jorge Gelman y Samuel Amaral se presenta un panorama totalmente renovado de la cuestión a partir del análisis de los libros de cuentas de un conjunto de grandes estancias de la región pampeana. Así, el primero de los autores citados constataba, para el siglo XVIII, la práctica del endeudamiento, pero asignándole un carácter marginal en las relaciones laborales de la época:

"Contra lo que quiere cierta historiografía tremendista que presenta al peón rural rioplatense poco menos que como un esclavo dice Mayo-, nosotros creemos que aquel fue verdaderamente libre: libre de entrar y salir del mercado de trabajo, libre del endeudamiento, libre de circular de estancia en estancia, de elegir empleador y de tomar ciertas licencias ante la rutina laboral [...] No estamos ante un caso de servidumbre, sino ante un precoz caso de asalariado libre." ${ }^{29}$

Los aportes que en este plano realizaron - junto a Mayo-Garavaglia, Gelman y Salvatore brindan un panorama más complejo de las relaciones sociales en el mundo rural rioplatense, en el cual uno de los factores que se resaltan como determinantes de las características de la formación social habría sido - a la par de la evolución demográfica, la disponibilidad de tierras, la acción del Estado y los propietarios y el efecto de ciertas coyunturas políticas - la propia intervención de los trabajadores, siempre dispuestos a resistir toda imposición que sobrepasase ciertos límites a su libertad de movimiento. De tales estudios resulta una visión coincidente con la de los críticos de las imágenes tradicionales del peonaje en América Latina, pues ponen de relevancia una capacidad de negociación y ciertos márgenes de independencia que aquellas se habían obstinado en desconocer u ocultar. En un artículo reciente,Jorge Gelman llega inclusive a la conclusión de que los inten-

Mayo, Carlos, "Sobre peones, vagos y malentretenidos: el dilema de la economía rural rioplatense durante la época colonial", Anuario IEHS, n ${ }^{\circ}$, Tandil, Buenos Aires, pp. 31-32. 
tos por imponer formas de trabajo compulsivo en la campaña bonaerense en la primera mitad del siglo XIX pueden considerarse un verdadero fracaso:

"[...] el ejemplo nos muestra también el fracaso de estos sistemas de trabajo coactivo, y en ello parecen estar interviniendo otro tipo de factores, que exceden ampliamente la situación de la economía y la demografía. En primer lugar la situación política, las sucesivas crisis que siguen a la revolución y que llevan a los gobiernos a una búsqueda de legitimidad que supera holgadamente a los reducidos sectores más enriquecidos de la sociedad. Pero además, y quizás sobre todo, es la intervención misma de los sujetos que se busca coaccionar, la que ayuda a entender en este caso el fracaso de la imposición de sistemas de trabajo coactivos duraderos [... $]^{30}$

\section{coerción y proletarización en Tucumán y Mendoza en la segunda mitad del siglo XIX}

Las visiones tradicionales sobre la condición del trabajador bajo las normativas laborales coercitivas fueron formuladas, para Tucumán, por Manuel García Soriano, y para Mendoza, por Arturo Roig. El primero, un historiador enrolado en el "revisionismo histórico" argentino, insistió - con matices- en el estereotipo forjado por la historiografía "liberal" para el caso pampeano, presentando un panorama decididamente "pesimista" sobre la suerte de las masas trabajadoras y su capacidad para modificar sus condiciones de existencia. Le cabe a García Soriano el mérito de haber sido el primer historiador tucumano que llevó al terreno de la historia la problemática del trabajo, reuniendo una nutrida

\footnotetext{
${ }^{30}$ Gelman,Jorge,"El fracaso de los sistemas coactivos de trabajo rural en Buenos Aires bajo el rosismo.Algunas explicaciones preliminares", op. cit.,p. 140 (las cursivas nos pertenecen). La renovada visión sobre el mundo rural rioplatense de estos autores está expuesta en Mayo, Carlos, Estancia y Sociedad en la Pampa, 1 740-1820, Buenos Aires: Biblos, 1995; Gelman, Jorge, Campesinos y Estancieros: Una región del Río de la Plata a fines de la época colonial, Buenos Aires, 1998; Garavaglia, Juan Carlos, Pastores y Labradores de Buenos Aires: Una historia de la campaña bonaerense, 1700-1830, Buenos Aires: Ediciones de La Flor-IEHS-Universidad Pablo de Olavide, 1999; Garavaglia, Juan Carlos, Poder, Conflicto y Relaciones Sociales: el Rio de la Plata, siglos XVIII y XIX, Rosario: Homo Sapiens, 1999. Un análisis crítico de estas visiones "renovadoras" (y una revalorización de los aportes "tradicionales") encontrase en Gresores, Gabriela y Martínez Dougnac, Gabriela,"En torno a la economía y la sociedad rioplatense en el siglo XVIII. Debates historiográficos actuales", Ciclos, n 3, Buenos Aires, 1992.
} 
información, tomada básicamente de la Sección Administrativa del Archivo Histórico de Tucumán y de la prensa local. Sin embargo, en tales trabajos -donde prima la denuncia de los métodos de explotación utilizados por la élite local- no están siquiera formuladas las cuestiones claves de la problemática: los objetivos que los sectores dominantes se proponían con la legislación coactiva, la mediación de la conducta de los trabajadores entre aquellos objetivos y los logros reales del sistema coactivo, y las causas de la derogación de la última de ley de conchabos, en 1896.

Para García Soriano, que ignora los antecedentes coloniales de la coerción laboral (es más, idealiza la legislación social de Indias), las leyes de conchabo implantaron en Tucumán un "sistema de trabajo semiesclavo", lo que atribuye a la identidad de intereses de "los unitarios liberales" con los patrones, a quienes considera "verdaderos" señores feudales. Como contrapartida, el trabajador tucumano del siglo XIX habría sido "un verdadero" siervo de la gleba, condenado a "una perpetua servidumbre", pese a que le reconoce su condición de asalariado."

En contradicción con esta apocalíptica imagen de la realidad social tucumana del siglo XIX, de los propios textos de este autor se desprende que los trabajadores sometidos "a perpetua servidumbre" enfrentaron pertinazmente los intentos de fijarlos a fundos y patrones, a menudo con éxito.

"La fuga de peones continuaba - dice refiriéndose a la década de 1860-; la cárcel se llenaba de peones deudores y, por otra parte, muchos propietarios ocultaban en sus fundos ajornaleros fugados, deudores de otros patrones. La policía tomó medida enérgica contra los patrones que ocultasen peones fugados [...] La ley de conchabos [de 1888] provocó una resistencia general de parte de los jornaleros de la provincia y de algunos espíritus progresistas que la criticaron duramente. A pesar de la energía con que se aplicó la ley, llenándose la cárcel dejornaleros y mujeres de servicio, muchos encontraron la manera de violarla, obteniendo, de favor, libretas de conchabo otorgadas por patrones ficticios." ${ }^{32}$

Casi quince años después del artículo pionero de García Soriano, Jorge Balán publicó los primeros resultados de una investigación desa-

García Soriano, "La condición social del trabajador en Tucumán durante el siglo XIX", Revisión Histórica, n 1, Tucumán, 1960, pp. 15,16, 23 y 24.

Ibíd.,pp. 22, 36-37. 
rrollada casi exclusivamente a partir del magnífico fondo de la BibliotecaTornquist. ${ }^{33}$ El tratamiento que da a la problemática es mucho más satisfactorio, en tanto identifica un conjunto de factores "estructurales" que explicarían las formas de reclutamiento de la mano de obra y la organización social de los sectores productivos en el marco de la expansión de la economía azucarera: el origen del capital y los capitalistas, la tecnología de producción predominante, sistemas de propiedad, etc., aunque también realiza pertinentes observaciones sobre las características de la fuerza de trabajo, la legislación represiva, los niveles salariales y las redes sociales que permitían la acción de los conchabadores, entre otros puntos. El aporte de Balán se detiene frente al comportamiento de los trabajadores, que habría de ser objeto de análisis posteriores. Sin embargo, en sus restantes contribuciones sobre Tucumán y el azúcar, no ha retomado la problemática.

Contemporáneamente a Balán, Donna C. Guy elaboraba -apoyándose por sobre todo en documentación del Archivo Histórico de Tucumán-su tesis doctoral, ${ }^{34}$ y publicaba en 1978 un interesante artículo sobre los trabajadores rurales y la coacción laboral en las plantaciones azucareras tucumanas. ${ }^{35}$ En dicho trabajo son tratados con solvencia e interrelacionados el contexto nacional, la evolución demográfica, el movimiento migratorio y los problemas de orden público e indisciplina social que acompañaron al auge azucarero. Guy plantea, además, un amplio espectro de interrogantes, referidos, en particular, a la conducta de los trabajadores y a sus estrategias de resistencia. La relación entre trabajadores matriculados y fugados de sus lugares de trabajo, los porcentajes de las deudas que resultaban incobrables para los patrones, etc., presentan un cuadro mucho más complejo del tema que el que había diseñado García Soriano. Las nuevas preguntas formuladas por Guy exigían apelar a nuevas fuentes, en especial las policiales, libros de empresa, el folclore, etc., sobre las que esta historiadora hace interesantes reflexiones. No obstante ello (y a la constatación de que entre 1876 y 1895 el incremento de los desórdenes sociales excedió,

Balan, Jorge, «Migraciones, mano de obra y formación de un proletariado rural en Tucumán, Argentina, 1870-1914». Demografía y Economía,Vol. X, 2 (29), México, 1976.

Guy, Donna, Política Azucarera Argentina, Tucumán y la generación del SO, Tucumán: Fundación Banco Comercial del Norte, 1981.

Guy, Donna, «The Rural Working Class in Nineteenth-Century Argentina: Forced Plantation Labor in Tucumán», Latin American Research Review, Vol. 13, n 1, 1978. 
por lejos, el crecimiento de la población, de igual modo que la propensión de los trabajadores a fugarse), las conclusiones a las que arriba dan una imagen de una clase trabajadora relativamente pasiva y "sin pocas alternativas, excepto trabajar bajo las condiciones impuestas por la oligarquía azucarera". ${ }^{36}$

Para el caso mendocino, la producción historiográfica referida a la problemática que nos ocupa es relativamente menor a la tucumana, pero comparte muchos de sus presupuestos básicos. Un destacado historiador de las ideas, Arturo A. Roig, afirmaba en 1969:

[.,..] El peón o la sirvienta [en Mendoza] son siervos en cuanto están atados no a la gleba, sino a un señor. No pierden la libertad de separarse de éste o aquel amo, pero no tienen derecho a vivir sin alguno. El control de esta servidumbre era precisamente lo que se pretendía alcanzar con la famosa "papeleta de conchabo". Otro de los caracteres de este tipo de siervo, que lo distingue de otras formas dadas históricamente, radica en que perciben una retribución, que a veces tiene la forma de salario y en que no pagan tributo $[\ldots]^{37}$

La confusión conceptual es similar a la de García Soriano, ya que el "siervo" mendocino de la segunda mitad del siglo XIX, según la sucinta descripción de Roig, no estaba atado a la tierra ni a un patrón en particular, sino sólo a su salario, que es lo que define al asalariado moderno. La superación de estas erróneas interpretaciones -que han cristalizado en verdaderos prejuicios que han pesado más que el estudio

Ibíd, pp. 141 y 143. Esta valoración negativa sobre la eficacia de la resistencia de los trabajadores en sus diversas formas es compartida por otros autores, sobre los cuales no creemos necesario hacer referencias puntuales. Por ejemplo, Eduardo Rosenzvaig, Historia Social de Tucumán y del Azúcar, Tucumán: UNT, 1987. La caracterización que hace este autor de la realidad social de Tucumán en el siglo XIX es -con terminología marxista- la de García Soriano, aunque no reconozca la paternidad de esas ideas al historiador revisionista. Un comentario crítico sobre la obra de Rosenzvaig, de Daniel Santamaría, encontrase en el Boletín del Instituto de Historia Argentina $y$ Americana Dr. Emilio Ravignani, $3^{\mathrm{a}}$ Serie, $\mathrm{n}^{\circ}$ 2, 1991. Cf., asimismo, Campi, Daniel, "Consideraciones críticas sobre dos aspectos del desarrollo azucarero tucumano: acumulación de capitales y captación forzada de mano de obra", Cuadernos de Humanidades, $\mathrm{n}^{\circ}$ 2, Facultad de Humanidades y Ciencias Sociales de la Universidad Nacional de Jujuy, 1991.

Roig, Arturo Andrés, «El concepto de trabajo en Mendoza durante la segunda mitad del siglo XIX. La polémica de 1873». En Contribuciones para la Historia de Mendoza, Mendoza: Universidad Nacional de Cuyo, 1969, p. 343. 
de las acciones concretas de los actores para definir la naturaleza de las relaciones sociales en ambos espacios provinciales- plantea como exigencia ineludible el estudio de las prácticas.

\section{una aproximación a las prácticas del mundo del trabajo}

Una constante llama la atención, tanto en Mendoza como en Tucumán, revisando las disposiciones de los gobiernos locales: la insistencia con la que se recordaba la vigencia de las normativas coactivas y las penas (para los trabajadores) y multas (para los patrones) establecidas para los que violaran su estricto cumplimiento. Se trata, sin duda, de una evidencia de que tales instrumentos legales eran de una efectividad más que relativa. Pese a que las élites agudizaban los esfuerzos para reducir al máximo la movilidad de los trabajadores con la retención por deudas, las respuestas de éstos al sistema coactivo no fueron pasivas. Los peones se fugaban con frecuencia buscando mejores oportunidades, escapando a regímenes de trabajo muy rigurosos, o como efectivo medio para evadir deudas (por anticipos salariales o por bienes adquiridos en almacenes o pulperías de sus patrones) difíciles de saldar. Denuncias como la efectuada por un patrón mendocino en 1857 contra un ex-peón, "un insigne ladrón", que se había fugado tres años antes, eran muy comunes: "En este invierno se presentó en este establecimiento [...] diciendo que debía a la hacienda y que quería pagar en trabajo, razón por [la] que el mayordomo lo admitió. Pocos días después se fugó debiendo en el almacén....". ${ }^{38}$

Estas conductas fueron sistemáticamente reprimidas y la policía asumió el rol de una especie de agencia de conchabos, en tanto capturaba trabajadores "prófugos" y "vagos", los entregaba a los patrones con "derechos" sobre los mismos o los colocaba con nuevos empleadores. En Tucumán, mientras a principios de la década de 1850 las detenciones por causas laborales eran poco significativas, su número se incrementó notablemente en los años 1860 y 70, junto al número de trabajadores registrados en la Oficina de Conchabos y las plantaciones de caña de azúcar. De acuerdo a los registros policiales, entre 1865 y 1886 , el 23,5 \% de los detenidos fueron trabajadores "prófugos" o "deudores" de sus patrones, con un porcentaje máximo de 37,7 en 1866 y un mínimo de 15,0 en 1879. Con todo, el porcentaje de "prófugos" dete-

Archivo Histórico de Mendoza, Carpeta 390, Documento 41. 
nidos sobre las denuncias efectuadas por los patrones (11.066 en 1889) nunca superó el 30 porciento y en algunos años apenas pasó el 10 porciento. ${ }^{39}$ Tal situación llevaba a que los propietarios fueran normalmente presentados como víctimas de sus dependientes:

"Los peones - se lee en un informe del Jefe de Policía de Tucumán de setiembre de 1869 - premunidos de que los patrones y la misma autoridad no pueden aplicarles una reprehensión severa por sus faltas, se fugan del servicio de sus patrones, se insolentan a cada paso negándose a cumplir con sus compromisos y aún se revelan (sic) a mano armada [...] En una palabra se han convertido en caballeros de industria que saquean impunemente a cuantos patrones que precisan de peones." ${ }^{40}$

Los críticos contemporáneos del sistema coactivo señalaban su flagrante contradicción con la Constitución Nacional, que consagraba el principio de la igualdad civil, y asimilaban la condición del trabajador a la de los siervos de la gleba." No obstante, más que un reflejo del ordenamiento social, las leyes de conchabo eran una representación ideal de la sociedad, un instrumento de acción de las élites sobre las relaciones sociales, un "deber ser" más que "el ser". Los trabajadores eran, en rigor, asalariados, y pese a que las normativas sociolaborales pretendían establecer derechos de propiedad de los patrones sobre el trabajo de quienes habían matriculado como peones "propios"- "derechos" que podían ser transferidos como cualquier bien patrimonial si mediaban deudas por anticipos de salarios o bienes-, fue imposible evitar que la mano de obra se movilizara bajo los impulsos de los in-

\footnotetext{
${ }^{39}$ Una información detallada sobre las detenciones de peones y sirvientes efectuadas entre 1865 y 1889 por el Departamento Central de Policía de Tucumán por aplicación de las disposiciones contra la vagancia ("fugas","faltas" y "deudas" a los patrones) está en Campi,Daniel y Lagos, Marcelo,"Auge azucarero y mercado de trabajo en el noroeste argentino, 1850-1930", en Silva Riquer,Jorge, Grosso,Juan Carlos y Yuste, Carmen, Circuitos Mercantiles y Mercados en Latinoamérica. Siglos XVIII y XIX, México: Instituto Mora-Instituto de Investigaciones Históricas de la UNA M, 1996, p. 471. Lamentablemente, no se ha conservado en Mendoza datos de este tipo que permitan elaborar series. Sin embargo, puede estimarse a partir de informes aislados que, en la década de 1880 , las detenciones por aplicación de las normativas laborales oscilaban entre un 10 y un 20 por ciento del total (El Ferrocarril, Mendoza, varios números, 1886; Anuario Estadístico de la Provincia de Mendoza correspondiente al año 1887, Mendoza, 1889, p. 76).
}

${ }^{40}$ Archivo Histórico de Tucumán, SA.Vol. 108,ff.488-489.

${ }^{41}$ Cf., Roig, op. cit. 
centivos monetarios. Fue a través de las fugas y de la contratación ilegal de peones "prófugos" que actuaron la oferta y la demanda, abriendo lentamente el camino a la constitución del mercado libre de trabajo. La misma práctica del endeudamiento por anticipo de salarios, presentada como una trampa que encadenaba de por vida a los trabajadores y obstaculizaba el desarrollo de un moderno mercado laboral, era el producto de una negociación previa a los contratos. Desde la misma perspectiva, a falta de sindicatos u otras formas de organización colectivas, el recurso de las fugas fortalecía la posición de los trabajadores para negociar salarios y condiciones laborales.

Pero el camino hacia un mercado de trabajo libre estuvo jalonado de marchas y contramarchas. En 1855 se reactualizaron las disposiciones coactivas en Mendoza a través de un decreto particularmente duro que normaba sobre la duración de los contratos e imponía a los trabajadores las multas, las prisiones y el trabajo forzado en obras públicas de rigor. Obligaba asimismo a los peones de tropas de arrias y carretas del mismo modo que se hizo en Tucumán en esos mismos años- a conchabarse "tan luego como llegaran de viaje", considerándoselos vagos si no obtenían de inmediato la papeleta. En 1867 el gobernador Nicolás Villanueva derogó el régimen de conchabo obligatorio y propició un sistema de libre contratación acorde con las disposiciones constitucionales. ${ }^{42}$ Esa decisión obedecía a posiciones liberales principistas de Villanueva, pero también apuntaba a eliminar o reducir a su mínima expresión las redes clientelares controladas por los grandes propietarios rurales, redes que tenían un innegable peso político en las elecciones y también en las rebeliones.

Sin embargo, en la década siguiente, una ordenanza sobre servicio doméstico de la municipalidad de Mendoza, de 1873, fue extendida por ley a todo el ámbito provincial un ã̃o después, quedando restaurada la papeleta. ${ }^{43}$ Aunque su aplicación fue irregular en los distintos

Decreto del 7.11.1867.

Ley del 31.8.1874. Modificó la Ley Orgánica de Municipalidades. El nuevo Art. 12 decía: «Las disposiciones que la Municipalidad de Ciudad dicte sobre el servicio doméstico, rejirá (sic) en toda la provincia». El municipio estableció, por ordenanza del 16.9.1874, la obligatoriedad de servir a un patrón a todo hombre mayor de 14 años o mujer mayor de 12 , que no tuvieran las consabidas artes o industrias lícitas de qué vivir. Para ello deberían portar una papeleta de conchabo que tendría una duración de 30 días, etc. Un decreto del gobierno provincial del 22.9.1874, dispuso aplicar esa Ordenanza en los departamentos de Tupungato, San Carlos, San Ra- 
departamentos y - de hecho- no rigió para los trabajadores europeos, mantuvo su vigencia hasta fines de siglo. La Ley de Estancias de $1880,{ }^{44}$ un verdadero código rural, derogaría, mediante su artículo 124 «[...] todas las disposiciones sobre el servicio doméstico que se opongan a la presente ley». Y las disposiciones que resultaban opuestas estaban referidas, precisamente, a la exigencia de la papeleta de conchabo para el trabajador rural, institución que esta nueva legislación, al no contemplarla, estaba excluyendo. ${ }^{45}$ Entonces, la «papeleta» que no entraba en colisión con la ley era la aplicable exclusivamente al personal del servicio doméstico. Ello explicaría la recurrencia con que algunas municipalidades, tanto la capitalina como las de campaña, dictaban ordenanzas que obligaban a los pobladores sin propiedades, artes u oficios, a servir a un patrón.

Esta real, si bien parcial, liberalización de las normativas en el ámbito mendocino no se dio en Tucumán, donde el Reglamento de Policía de 1878 reproducía, con variantes no muy importantes, las disposiciones del reglamento de 1856. Quizás la mayor "hambre de brazos" de la élite tucumana, en momentos en que la expansión azucarera se potenciaba con la llegada del ferrocarril, explique la decisión de no renunciar a imponer los viejos vínculos de dependencia, los que sin embargo estaban en un lento proceso de desintegración como efecto de las conductas refractarias de los trabajadores. En consecuencia, las leyes de conchabo y la persecución a la "vagancia" se aplicó también a los inmigrantes europeos, que pronto demostraron ser tan "indóciles" e "indolentes" como los desacreditados trabajadores criollos. En realidad, no pudieron adaptarse a las exigencias del corte de la caña y del trabajo en los ingenios y a la dieta alimenticia (como tampoco pudieron hacerlo los indios pampas que fueron enviados a Tucumán luego de la "conquista del desierto"), a lo que deben agregarse expectativas sala-

fael, La Paz y Rosario, es decir en zonas de campaña más alejadas en las que se hacía más necesario el control de las peonadas para ganar las elecciones y para retener la fuerza de trabajo (Registro Oficial 1873-1874, pp. 467; 532; y 533-534, respectivamente).

Ley del 12.5.1880 (Registro Oficial 1880, pp. 222-245).

45 La ley mejoraba, además, algunas condiciones laborales para los empleados mensualizados o permanentes, tales como horarios de trabajo, días de descanso o contratos escritos, monto del salario, etc. (Arts. 104, 105 y 106); pero los jornaleros mantenían una extrema precariedad y desprotección. Se conservaban, también, ciertas restricciones a la movilidad de los trabajadores (Art. 112). 
riales insatisfechas y el rechazo al régimen del conchabo obligatorio, ${ }^{46}$ razones que pueden explicar en parte la relativamente pobre afluencia a esta provincia de la inmigración europea con relación al litoral y a Cuyo. No está de más aclarar que los inmigrantes laboralmente calificados, contratados como técnicos en los ingenios azucareros con niveles salariales relativamente altos y aquellos que se radicaban en el medio urbano con oficios "respetables", escapaban a los rigores del conchabo obligatorio.

La conexión ferroviaria de Tucumán con el litoral en 1876 y las perspectivas que despertaba en Mendoza esa posibilidad, hicieron vislumbrar a las clases propietarias la inevitabilidad del mercado de trabajo libre. "Así que vengan con el Ferrocarril, les han de pagar un peso a cada gañán y no hemos de tener quien nos alcance unjarro de agua", se quejaba en Mendoza, ya en 1871, un "suscriptor" de El Constitucional." En Tucumán la competencia del ferrocarril ocasionó grandes dolores de cabeza a los empresarios ávidos de mano de obra. A principios de la década de 1880 , más de 3.600 peones estaban ocupados en las obras de prolongación al norte, 2.500 de ellos en los trabajos de corte y construcción de terraplenes. ${ }^{48}$ La competencia del ferrocarril afectaba inclusive a los contratistas de los ingenios enviados a reclutar trabajadores a Santiago del Estero y Catamarca por los mejores salarios ofrecidos por los empresarios del riel. ${ }^{49}$ En Mendoza las obras del ferrocarril harían realidad la previsora observación del "suscriptor" de 1871. A comienzos de los años achenta el Ferrocarril. Andino requería trabajadores para tender los rieles desde Villa Mercedes (en la vecina provincia de San Luis), con un sueldo nominal de 25 pesos fuertes, incluyendo gastos de comida (lo que hacían un neto de 16 \$F). ${ }^{\text {so }}$ Para

\footnotetext{
${ }_{46}$ "Los mismos inmigrantes que se presentan hoy como huyendo de la provincia por el hambre y las necesidades, habrían podido acomodarse en los ingenios de azúcar si se hubiesen contentado con el salario mensual de 20 \$ nacionales. Pero no, no lo quisieron, sus exigencias reclamaban mucho más y he aquí que se han alejado de una provincia que les brinda trabajo y protección" (El Ordem,Tucumán, 23.2. 1885).

${ }^{47}$ El Constitucional, Mendoza, 26.9.1871.

${ }^{48}$ La Razón, Tucumán, 9.4.1884.

${ }^{49}$ "En Santiago y Catamarca no hay peones en disponibilidad. Hoy prefieren emplearse en los trabajos de los ferrocarriles ganando 30 \$ mensuales, que venir a la Provincia de Tucumán con 14 \$ y la comida" (El Orden,Tucumán, 31.12.1888).

so"El Constitucional", Mendoza, 4.11.1880; El Ferrocarril, Mendoza, 17.2.1882.
} 
1883, sólo una sección de 25 kilómetros en construcción empleaba 600 obreros y no incorporaba más por fallas en la provisión de materiales para la obra." El nuevo medio de transporte incidía así directamente en la formación del mercado de trabajo, en la oferta voluntaria de mano de obra, en la movilidad territorial de los peones y, obviamente, en la elevación de los salarios.

En la provincia cuyana la preocupación por el costo de los salarios promovió propuestas para mecanizar la agricultura, a través de lo cual se lograrían aumentos de productividad y una sustancial reducción de la mano de obra empleada. Se pensaba que con las máquinas "encontraremos los brazos a bajo precio, que es lo que nos conviene". De ese modo, las segadoras y sembradoras permitirían cultivar grandes extensiones y cosecharlas en corto tiempo "sin tener que estar subordinados a la voluntad y capricho de los peones que en esas épocas suelen ponerse caros y escasos". ${ }^{52}$

Pese a tales previsiones, y a la persistencia de la coacción, los salarios de los trabajadores tendieron a subir. Aunque se trataba de un salario de tipo antiguo, con un componente monetario y la ración alimenticia, los vigentes en Tucumán pronto se despegaron de los de Santiago del Estero y Catamarca, vigorizándose el flujo de migrantes que año tras año partían de esas provincias en la época de la zafra azucarera. No obstante, hubo que esperar a fines de los años ochenta y principios de los noventa para que los salarios se incrementaran de un modo significativo. En rigor el salario real del trabajador azucarero tucumano sólo comenzó a subir en 1890 (entre un 20 y un $40 \%$ con relación a 1880)..$^{53}$

Del mismo modo que ocurrió con el auge azucarero, ya con la expansión del oasis y la valorización de nuevas tierras para atender la creciente demanda chilena de ganado, se fortaleció la afluencia de trabajadores trasandinos a Mendoza, pues la economía de esta provincia les aseguraba mayores ingresos salariales y mejores perspectivas, comparadas con las duras condiciones de existencia de los gañanes en Chile. En la década del 1880 , los salarios comenzaron a aumentar conside-

El Constitucional, Mendoza, 8.11.1883.

Informe de L. González y R. Videla. El Constitucional, Mendoza, 28.10 y 2.11 .1871 .

s3 Cf., Campi, Daniel y Sánchez Wilde, Andrés, "Mercado de trabajo y evolución del salario real del peón azucarero en Tucumán, 1881-1893",comunicación presentada en el Encuentro Internacional de Historia. El siglo XIX, Bolivia y América Latina, Sucre, 25-29 de Julio 1994. 
rablemente, pese a que el ferrocarril trasladaba desde 1885 cantidades crecientes de inmigrantes de ultramar, los que sumaron 6.737 en el quinquenio 1886-1890. ${ }^{54}$ Entre 1886 y 1888 los sueldos y jornales pagados en los departamentos se habrían duplicado, ${ }^{5 s}$ probablemente porque al concentrarse los europeos en la ciudad capital y alrededores, la oferta de trabajadores era insuficiente para desarrollar los nuevos viñedos y bodegas. Asimismo, los altos salarios iniciales y los bien pagados trabajos a destajo promovieron, desde los años 1890 , la constitución de una clase de pequeños propietarios vitivinícolas relativamente prósperos, fenómeno que no tiene correspondencia en el caso tucumano."

De lo expuesto se puede presumir que si los peones se ponían "caros" es porque había - pese a las disposiciones que restringían su libertad-ciertos márgenes de movimiento y de puja por el precio del trabajo. Por lo demás, parecía evidente que el problema de la escasez de la mano de obra que desvelaba a las clases propietarias no podía resolverse con el expediente de aplicar mayor rigor para lograr que las normativas coactivas fuesen respetadas estrictamente por peones y patrones. Tal salida no dejó de ser un reclamo recurrente de algunos propietarios, pero fue perdiendo consenso entre las élites políticas tucumanas y mendocinas, proceso que no fue simultáneo y que tuvo facetas tanto comunes como divergentes en ambas provincias.

\section{la extinción del sistema coactivo}

Aunque - como se ha sostenido en estas páginas - el déficit de la oferta laboral con relación a la demanda explica la revitalización de las instituciones y mecanismos coactivos que perseguían restringir la mo-

${ }^{4}$ Martín, JoséF., "Políticas estatales y conformación de una burguesía industrial regional", Cali, 1981, mimeo.

ss Lemos,Abraham, Mendoza. Memoria Descriptiva de la Provincia,Mendoza, 1888,p. 63.

${ }^{56}$ En Tucumán, la presencia en el paisaje social de un importante segmento de pequeños propietarios dedicados al cultivo de la caña de azúcar debe atribuirse a una estructura agraria caracterizada por la extendida subdivisión de la propiedad que resistió al proceso de concentración fundiaria que acompañó el auge azucarero. Además, los minifundistas cañeros de ningún modo accedieron a la "prosperidad" que gozaron los pequeños productores viñateros mendocinos. Cf, Bravo, María Celia, "El campesinado tucumano: de labradores a cañeros. De la diversificación agraria hacia el monocultivo", Población \& Sociedad, n 5, 1997. 
vilidad de los trabajadores en la segunda mitad del siglo XIX, los mismos no pudieron evitar el desarrollo de un mercado libre y unificado de trabajo. En efecto, la coacción laboral hizo crisis en las décadas de 1880 y 1890, anticipándose en esto Mendoza a Tucumán en varios años.

En el primer caso, el régimen de la papeleta de conchabo comenzó a extinguirse, en la práctica, a mediados de los años ochenta. Aparentemente, a principios de aquella década estaba en desuso la disposición que extendía a los departamentos de campaña la ordenanza municipal de la Capital sobre el servicio doméstico, porque no se ha encontrado ningún instrumento legal derogatorio.Y, pese a que, en 1883,1a Municipalidad de la Capital insistía, con una nueva ordenanza, en reinstaurar la papeleta en su jurisdicción, su cumplimiento efectivo enfrentaba serios obstáculos. Así, en setiembre de 1884, un perplejo jefe de policía solicitaba al Ministro de Gobierno de la provincia instrucciones al respecto:

"El reglamento municipal sobre servicio doméstico del 24 de octubre del año ppdo. exige en su artículo $1^{\circ}$ que todo hombre mayor de 14 años o mujer mayor de 12 que no tengan bienes propios suficientes, o un arte o industria lícita de qué vivir, sin depender de otra persona, deberán tener patrón a quien servir; lo que hará constar en una papeleta [... Cumpliendo con lo dispuesto en el inciso $5^{\circ}$ del artículo $3^{\circ}$ del Reglamento de Policía este departamento ha hecho lo posible para que esta ordenanza se cumpla, sin embargo de las serias dificultades que se tienen en la práctica y de la [sic] desfavorable concepto que ha merecido ante la opinión pública por creer que ella ataca los derechos individuales [...]

En la fecha se encuentran detenidos más de veinte individuos que dicen ser peones de la Empresa de Prolongación del Ferro Carril Andino por falta de papeleta [...] La empresa no los ha reclamado como tales peones, y no da tampoco papeleta de conchabo.

Ahora, lo que motiva la presente es la duda en que me encuentro para hacer efectiva la Ordenanza Municipal pues constándome que la detención de los peones de la Empresa no puedo castigarles por falta de papeleta que acredite un trabajo, ni puedo ponerlos en libertad por no haber llevado un requisito ordenado por la Municipalidad de esta ciudad. No se puede tampoco compeler a la Empresa del Ferro-Carril a que cumpla la ordenanza municipal expidiendo papeleta a todos los empleados de su servicio, porque la Ordenanza no prevee [sic] este caso y no contiene, por consi- 
guíente, disposición penal alguna contra los patrones que se nieguen a cumplirla." ${ }^{57}$

En este caso particular, la insistencia municipal no se oponía a la Ley de Estancias de 1880 , ya que esta sólo legislaba para establecimientos rurales (estancias, chacras, quintas, haciendas), sin incursionar en el mercado de trabajo urbano. Pero era el municipio que chocaba, como se aprecia, con la cerrada oposición de la empresa ferroviaria del Estado nacional, lo que motivaba el planteo del jefe policial. Ante una opinión pública adversa al sistema y la negativa de la empresa a emitir las papeletas, el funcionario manifestaba la imposibilidad de dar cumplimiento la ordenanza, sobre cuya necesidad, además, parecía no estar muy convencido. ${ }^{58}$

En Tucumán, en la década de 1880 los críticos de la papeleta y de la retención por deudas no estaban en condiciones de imponer sus puntos de vista. En la "opinión pública", que obviamente recogía las voces de los sectores dominantes, predominaban todavía las de quienes eran partidarios del sostenimiento de la coacción laboral. Ello obligará al gobernador Lídoro Quinteros a modificar radicalmente su postura entre 1887 y 1888. El primero de esos años había afirmado en su primer mensaje como gobernador a la Asamblea Legislativa que "las disposiciones sobre el trabajo ajornal" del reglamento del policía de 1877

"[..] son contrarias a la libertad del trabajo mismo, a la garantía del salario y aún a la independencia individual. Tuve oportunidad de expresar mi pensamiento al respecto cuando me recibí del Gobierno, y hoy lo confirmo solemnemente al ver que el juicio unánime de la prensa de la República recogió esa promesa con franca satisfac-

Archivo Histórico de Mendoza, Carpeta 181-Policía, Documento 9.

ss De todos modos, el comportamiento de las autoridades policiales mendocinas no lograba definirse totalmente en contra de la aplicación del régimen de la papeleta. Según se desprende de un editorial de Los Andes, en 1886 la fuerza pública perseguía a los trabajadores que no portaban la papeleta: "[a los pobres] no se les concede otro derecho que el de humillarse a las plantas de los que mandan [...] Al pobre le es prohibido salir a la calle sin ir munido de una papeleta donde su patrón, porque se le obliga a tenerlo, certifica que le trabaja [...] Si a ese pobre se le ocurre trabajar por su cuenta y vivir independientemente, la autoridad se lo impide, aplicándole multas por falta de papeleta y por holganza. El reglamento sobre servicio doméstico, que es un cúmulo de disparates [...] es uno de los medios de que las autoridades se valen para humillar y perseguir al pobre" (Los Andes, Mendoza, 13/1.1886). 
ción, quizá porque llevaba en sí misma lo que la experiencia de otros pueblos más adelantados y aun la nuestra propia, ha confirmado con la ciencia económica: en el trabajo libre reposa la mayor riqueza.

Pero en 1888 promovió la ley de conchabos, una versión corregida del capítulo sobre "vagos, jornaleros y domésticos" del Reglamento de Policía de 1877. La nueva ley, si bien contenía algunas innovaciones que ponían a los trabajadores en una situación menos desfavorable frente a los patrones, ${ }^{\circ 0}$ seguía haciendo obligatorio el trabajo bajo el régimen de la papeleta y consagraba igualmente la retención por deudas. ${ }^{61}$ La ley mendocina del ochenta, sin dudas más liberal que las normas tucumanas, en tanto eliminaba la papeleta, colocaba sin embargo a los trabajadores en una situación muy desfavorable en los conflictos por la cuestión de los "anticipos".62

Sin duda fue la tenacidad con la que algunos sectores de las clases

${ }^{59}$ Compilación Ordenada de Leyes, Decretos y Mensajes de la Provincia de Tucumán,Vol. XII, Tucumán, 1916, p. 277.

${ }^{60}$ Por ejemplo, mientras los reglamentos de 1856 y 1877 disponían que cualquier litigio relacionado con arreglos de cuentas se resolvería de acuerdo a las anotaciones contenidas en los libros de los patrones, a partir de 1888 debían tenerse por válidas las anotaciones efectuadas en las libretas de conchabo, las que - expedidas por la policía- permanecerían en poder de los trabajadores.

${ }^{6}$ En rigor, el proyecto de ley de conchabos puesto a consideración por el gobernador Quinteros fue duramente cuestionado por un grupo de senadores, que logró imponer en la cámara respectiva numerosas modificaciones favorable a los trabajadores (la pérdida de los derechos de los patrones sobre deudas por anticipos de salarios, prevista a partir del 31 dejulio de 1890; las mayores restricciones para aplicarla a menores de edad; y una moderación de las penas contempladas para los peones que cometieran infracciones, eran las más importantes). Aunque el Senado insistió en su postura, los intereses de los grandes tomadores de mano de obra (industriales y plantadores de caña de azúcar) primaron en la Cámara de Diputados, revirtiendo muchas de esas reformas, en particular la que aludida a la retención de trabajadores por anticipo de salarios (Compilación Ordenada de Leyes, op. cit.,Vol. XIII, pp. 297 377).

${ }^{62}$ El articulo 113 establecía que cualquier duda que surgiese entre el patrón y sus empleados «acerca del monto de las anticipaciones...» sería resuelta por el Juez con arreglo al «Libro de Cuenta» que debía llevar el propietario, a lo que se agregaría el juramento de éste. Es decir, la cuestión se dirimía entre el juez y el patrón, sin participación del trabajador. En este sentido, el hecho de que la ley tucumana reconociera a los peones el derecho a tener en sus manos las libretas de trabajo, suponía un mayor grado de protección para éstos y les otorgaba un poder de negociación sobre el endeudamiento superior a sus pares mendocinos. 
propietarias tucumanas defendieron la coacción laboral contra viento y marea lo que hizo necesaria una ley derogatoria específica, la que recién se aprobaría en los primeros meses de 1896. De todos modos, entre 1892 y 1894 , el cumplimiento de la legislación fue muy irregular, aunque la ley de conchabos no fue derogada ni cayó totalmente en desuso. El gobernador Próspero García, partidario de la liquidación del sistema de la papeleta, suprimió del presupuesto de la provincia la partida destinada a sostener la Oficina de Matrículas luego de que la Legislatura rechazara en 1891 una iniciativa suya en ese sentido.

En este último año se habían matriculado 38.061 trabajadores (se disponen cifras hasta mediados de octubre). Pero de enero a setiembre de 1892 se habían expedido solamente 2.195 libretas de conchabo y 353 papeletas de peones prófugos. ${ }^{63}$ A su vez, dejulio de 1892 al 18 de junio de 1893, la Policía sólo habría entregado 6.736 libretas, ${ }^{64}$ situación que indujo a algunos particulares a reclamar airadamente a través de la prensa el estricto cumplimiento de las disposiciones relativas al conchabo. ${ }^{65}$ Recién en 1895 el trámite de la inscripción formal de los peones conchabados en los registros policiales adquirió visos "normales", con 34.181 matriculados, ${ }^{66}$ pero cayó nuevamente a pique al año siguiente, lo que puede explicarse por la circunstancia de que si bien formalmente la ley tuvo vigencia hasta el 11 de diciembre de aquel año, en la práctica el sistema se vino abajo desde el momento en que se votó su derogación en el mes de mayo. ${ }^{67}$

Quizás la sagaz observación de Gibson sobre la derogación legal del repartimiento en Nueva España en el siglo XVII sea aplicable al caso tucumano:

"En la historia de México casi nunca se han producido cambios significativos establecidos por la ley. La ley es una aproximación del acontecer histórico, o un comentario sobre el mismo. En el caso de la abolición de 1632 [del sistema del repartimiento] sería un error suponer que el trabajo de repartimiento llegó a su fin o que sólo la ley fue responsable de la transición a otras formas de organización

${ }_{63}$ El Orden, Tucumán, 6.9,1892.

${ }^{64}$ Ibid., 19.6.1893.

" Ibid., 28.2.1894.

${ }^{6}$ Anuario Estadístico de la Provincia de Tucumán, 1895, Buenos Aires, 1896,Vol. II, pp. $462-463$.

${ }^{67}$ Una serie completa de los peones conchabados en los registros oficiales en Campi y Lagos, op. cit., p. 469. 
laboral. Es verdad que, en lo sucesivo, el repartimiento no tuvo un papel importante en el trabajo agrícola. Pero también es verdad que tuvo un papel sin importancia en el períodojustamente anterior a su abolición [... . "68

En otras palabras, el deterioro de la institución del conchabo forzoso precedió a su derogación legal. La cuestión consiste, entonces, en determinar qué descalabró el sistema en la vida real, cuáles fueron las fuerzas sociales y los actores que con sus conductas y estrategias lo horadaron y lo hicieron inviable. Una de las claves de la derogación del sistema estaría en los elevados costos de su sostenimiento y en la certidumbre, para algunos sectores de la élite, de que esos costos eran desproporcionadamente altos con relación a sus cada vez más inciertos beneficios. No se trataba solamente del costo de los sistemas de control -estatales y privados-, en nada despreciables; ni de las grandes pérdidas ocasionadas por las fugas de peones fuertemente endeudados. ${ }^{69}$ Para algunos era la misma productividad del trabajo la que se veía afectada y ello no podía sino reafirmar la verdad incontrastable del superior rendimiento del trabajador libre de toda coacción. Con este argumento, entre otros, fundamentaba Próspero García su intento de derogar la ley de conchabos en 1891:

"[...] el enganche del jornalero lleva el estímulo o la necesidad hasta el extremo de convertir a los patrones en postores para hacer subir el adelanto de dinero por servicios a prestarse, y que muchas veces no se prestan, porque el peón, cargado de una deuda considerable, convencido de que no podrá pagarla, toma el recurso de la fuga o trabaja con desventaja para el patrón. Así, el recurso del adelanto que se emplea es perjudicial para el patrón y corruptor para el jornalero. Es un error creer que el adelanto al peón proporciona

\footnotetext{
${ }^{68}$ Gibson, Charles, op. cit., p. 240.

${ }^{69}$ En 1886 una "Comisión de Industriales" tucumanos, con la firma de José Padilla, Máximo Etchecopar y Justiniano Frías se dirigía a las autoridades provinciales haciendo un diagnóstico del estado de la industria azucarera. En ella afirmaban que los graves problemas por la que ésta atravesaba se originaban, entre otros factores, en "[...] el excesivo precio de la mano de obra, por el alto salario que ganan los peones, el capital que hay que emplear en adelantos a los mismos, la parte de ese capital que se pierde por los peones que lo reciben a cuenta y no regresan voluntariamente o por las arbitrariedades que con ellos cometen las autoridades de otras provincias no permitiéndoles salir de su territorio, y la escasez de brazos que aumenta día a día [...)" [La Razón,Tucumán, 20.7.1886).
} 
mayor número de brazos, y si algo se consigue en ese sentido, se pierde en calidad de servicios, porque eljornalero deudor no trabaja como el que está libre de deudas. Esto que es elemental en teoría, lo es más en la práctica $[\ldots]^{7 \% 0}$

Este efecto de las conductas de las peonadas, reacias a aceptar mansamente la coacción y hábiles para sacar provecho de los resquicios del sistema y de la puja entre los patrones por la mano de obra, habría apurado la resolución de las contradicciones que en lo que respecta al régimen de la papeleta era evidente en el liberalismo criollo de fines del siglo XIX: la oposición entre el respeto del principio de la libertad (que conllevaba el derecho al trabajo en lugar de la obligación al trabajo) y el recelo que despertaba el goce del mismo por las clases populares. ${ }^{71}$

Está claro que tal resolución no podía hacerse sino en una dirección, la de la derogación del sistema, aunque el proceso generó no pocas resistencias.Tanto la prensa mendocina como la tucumana reflejaron la tensión que generaba en el seno de las élites locales el problema, determinando que un mismo órgano de prensa modificara varias veces su posición. Como vimos, en abril de 1886 "Los Andes" denunciaba como algo oprobioso la imposición del uso de la papeleta a los pobres; pero en diciembre de 1887 -también en un editorial- reclamaba la aplicación de la ordenanza municipal sobre el servicio doméstico, y lo vuelve a hacer febrero de 1888 , en noviembre de 1891 y en marzo de 1893 , para

Compilación Ordenada..,Vol.XX, Tucumán, 1919,f. 159.

Al respecto, bien podría aplicarse la explicación que propone Bauer para el conjunto de las élites hispanoamericanas:"[...] la opinión de las elites a finales del siglo XIX generalmente era contraria al peonaje y al empleo de contratistas de mano de obra - el sistema llamado 'enganche'- excepto cuando se consideraba que ello era absolutamente indispensable para formar una fuerza de trabajo disciplinada. 'El trabajo libre produce más', descubrió un delegado en un congreso agrícola de 1896 en Chiapas (México), mientras otros, preocupados por la imagen negativa que podían hacerse países de los que tal vez podría obtenerse capital, recordaron al congreso que el sistema de trabajo en Chiapas era una vergüenza para el 'mundo civilizado'. Si bien estas actitudes eran cada vez más comunes entre los hombres que dirigían Hispanoamérica entonces, coexistían incómodamente con la opinión paralela de que las clases bajas rurales, fruto del fatalismo indio y de la pereza negra, eran incurablemente holgazanas, sólo trabajaban como era debido cuando las azotaban y tal vez no serían susceptibles al progreso" Bauer, Arnold,"La Hispanoamérica rural, 1870-1930", en Bethell,Leslie (Ed.), América Latina: economía y sociedad, c. 1870-1930, volumen 7 de la Historia de América Latina de Cambridge University Press, Barcelona: Crítica, 1991, p. 145. 
cambiar nuevamente de posición y retomar la defensa de los trabajadores en $1896 .^{72}$ La línea que sostuvo el tucumano El Orden no fue menos errática. En 1884 y 1886 publicaba notas condenando la "vagancia" y reclamando "medidas enérgicas" de la policía para "extinguirla"; en 1888 se pronunciaba contra la sanción de la ley de conchabos por sus disposiciones contrarias a la Constitución, al Código Civil y a la libertad; en 1889 condenaba a la policía, pero esta vez por no aplicar con rigor la ley de conchabos a los trabajadores en huelga de las sastrerías; en 1890 solicitaba la represión de una serie de estrategias con las que los trabajadores lograban eludir las disposiciones de la ley; en 1891 se pronuncia por la derogación de la "monstruosa ley de conchabos"; en 1893 insiste en la necesidad de la derogación, pues se trataba de una ley "tiránica" e "inconstitucional"; en 1895 realiza una entusiasta de fensa de la misma, pues habría constituido la única garantía contra la vagancia,"un mal social" que se debía "combatir con energía"; en 1896, ante los hechos consumados de la derogación (votada en febrero en la Cámara de Diputados y sancionada por la de senadores el 9 de abril), combina una justificación de las críticas al sistema coactivo, con un llamado de alerta contra los problemas que se generarían por falta de mano de obra y contra el "vacío" legal en las relaciones laborales que sucedería a la derogación. La consigna que enarbola en abril de 1896 resume como ninguna las contradicciones del liberalismo tucumano: "Libertemos al peón y combatamos la vagancia". ${ }^{73}$

Si el problema de las pérdidas por la fuga de peones endeudados fue uno de los factores que puso en duda la conveniencia de sostener el sistema, no debe descartarse la incidencia de otros elementos, como el interés de los medianos productores de terminar con reglamentos y prácticas que los hacían competir en desventaja en la captación de la mano de obra con los grandes industriales y terratenientes; ${ }^{74}$ la percepción de que la coacción laboral desalentaba el flujo migratorio europeo; las tendencias reformistas encarnadas por algunos gobernadores;

Los Andes, Mendoza, 13.4.1886; 8 y $11.12 .1887 ; 2.5 .1888 ; 8.11 .1891 ; 10.3 .1893$ y 14.4.1896.

"El Orden,Tucumán,26.4.1884; 15.5.1886:20,21 y 24.8.1888:5.10.1889;4.1.1890; $19.12 .1891 ; 12$ у $17.4 .1893 ; 23,24$ у $26.12 .1895 ; 10.4,15$ у $18.9,28.10,9$ у 21.11 , 10 y 12.12 .1896 .

Donna Guy pone énfasis en este factor para explicar la derogación de la ley de conchabos en Tucumán (Guy, Donna, Política Azucarera Argentitna:Tucumán y la Generación del 80, Tucumán: Fundación Banco Comercial del Norte, 1981, p. 108). 
el conflicto de intereses desatado en Tucumán entre algunos patrones y el Estado nacional, el que en la década de 1890 no respetaba los "derechos" de los particulares sobre la mano de obra y "enganchaba" para el ejército a peones fuertemente endeudados, y la fuerte presión que ejerció una campaña en la prensa de la ciudad de Buenos Aires contra la papeleta. $^{75}$

Este cuadro puede explicar que, existiendo en esta última provincia sectores partidarios del sistema coactivo, la derogación de la ley de conchabos haya sido aprobada con el voto unánime de todos los legisladores sin que se haya planteado en las cámaras un duro debate y sin que se haya fracturado ni Asurado el bloque de poder. La presencia de una oficina de "enganche" del ejército nacional y los conflictos que generó el reclutamiento de peones endeudados puso en evidencia que una ley provincial no podía afectar la política nacional de reclutamientos. ${ }^{76} \mathrm{Ni}$ los oficiales de la Guardia Nacional estaban dispuestos a respetar la anacrónica ley local, ni la policía ni el gobierno provincial deseaban enfrentarse con los poderes nacionales. Además, para importantes sectores de la élite la supresión del régimen del conchabo obligatorio no traería como consecuencia las catástrofes que preanunciaba El Orden, periódico que expresaba la postura más conservadora del liberalismo tucumano frente al tema.

En Mendoza no fue necesaria siquiera una ley derogatoria específica. La Ley de Estancias quitó sustento al régimen de la papeleta porque establecía diferencias entre los trabajadores rurales y urbanos, protegiendo, si cabe la expresión, a los primeros. Pero el trabajador urbano

\footnotetext{
${ }^{75}$ En abril de 1896, en una editorial titulada "Ley de Conchavos", Los Andes transcribía una circular de la Federación Obrera Argentina firmada porJosé Ingenieros y Adrián Patroni que llama a una manifestación contra las leyes de conchabo que regían en Tucumán, Salta, Santiago del Estero, San Luis, Catamarca, Córdoba, Misiones y otras provincias, consideradas violatorias de los derechos de los trabajadores (Los Andes, Mendoza, 14.4.1896).

${ }^{76}$ En abril de 1894 El Orden iniciaba una serie de denuncias contra la acción de la "Oficina de Enganche", que tuvo continuidad en 1895 y $1896:$ : [... algunos de los oficiales encargados en esta de hacer el enganche, van por la campaña armando baile y fiesta de lugar en lugar a objeto de embarcar peones conchabados y que deben plata a sus patrones para incluirlos en el enganche. Mientras exista la ley de conchabos, las autoridades de la provincia tienen el deber de proteger los intereses de los propietarios, que adelantan dinero a sus peones fiados en la citada ley y que se ven burlados y perjudicados en sus intereses si se permite a esos peones deudores, irse en el enganche sin satisfacer sus deudas ni dar cumplimiento a los compromisos de su conchabo" (El Orden, Tucumán, 17.4.1894).
} 
no podía ser sometido a estas instituciones coactivas indefinidamente por la propia naturaleza de su ámbito laboral. En efecto, al estar en un espacio geográfico ciudadano, vinculado funcionalmente con otras ciudades mayores de las que se recibe un constante flujo de nuevas ideas e informaciones; y en el que los cambios son siempre acelerados por los fenómenos de circulación y difusión, era insoslayable que surgirían resistencias de todo tipo contra los mecanismos coactivos." La decadencia se hacía evidente, por lo demás, porque se intentó prolongar el régimen de la papeleta sólo a través de ordenanzas municipales, como ocurrió en la Municipalidad de San Martín y otras de la campaña, según una denuncia de la prensa de febrero de $1896,{ }^{78}$ lo que lo privaba de un sustento legal tan sólido y duradero como el que tuvo en Tucumán. La reinstauración en espacios jurisdiccionales tan reducidos facilitaban la resistencia y el traslado de los trabajadores a otros municipios, anulando, de hecho, los efectos de esas ordenanzas. Finalmente, la nueva Constitución Provincial de 1900, en cuyos artículos 31 y 32 se garantizaban el derecho a la movilidad geográfica de las personas y la libertad de trabajo, industria y comercio; ${ }^{79}$ y el Código de Policía, del mismo año, que dejaba de considerar a la vagancia como un delito, ${ }^{80}$ liquidarían para siempre las posibilidades de imponer el trabajo como obligación.

\section{breves consideraciones finales}

La conformación de un mercado de trabajo libre de la carga coactiva del sistema de la papeleta de conchabo y de la retención por deudas tuvo en ambos espacios provinciales características muy semejantes,

\footnotetext{
«La concentración del poder que se produce en la ciudad abarca tanto al poder institucionalizado como al no institucionalizado [...]. Pero, además, es en la ciudad donde se alojan los grupos que ejercen más vigorosamente el poder no institucionalizado.Vinculados a las actividades básicas de la colectividad, los grupos de poder y los grupos de presión operan preferentemente en la ciudad, cerca del poder institucionalizado y cerca también de los distintos sectores sociales que pueden ser movilizados a favor de ciertas opiniones y exigencias» Romero, José Luis, «La ciudad latinoamericana y los movimientos políticos», Siglo XIX Revista de Historia $n^{o}$ 11, México, 1992, p. 16, artículo reproducido de la primera versión, 1966.

${ }^{78}$ Los Andes, 8.2.1896.

${ }^{79}$ Registro Oficial de la Provincia de Mendoza. 1900,Tomo I,pp. 122-123.

${ }^{80}$ Ibíd., Tomo I, p. 18.
} 
en particular si atendemos a las estrategias de los trabajadores y a sus efectos. Sin embargo, en Tucumán el sistema tuvo bases legales más sólidas, fundado siempre en instrumentos aprobados por la legislatura provincial, lo que explicaría que el proceso de extinción en la práctica de las normativas coactivas comenzara a manifestarse varios años después que en Mendoza. Por otro lado, no poca influencia habría de tener la mayor incidencia de la inmigración europea en la provincia cuyana, lo que complejizó en mayor grado la sociedad y creó una clase de pequeños y medianos propietarios cuyo peso económico y político relativo habría sido mayor al de los medianos y pequeños productores rurales de la provincia norteña. En ésta, por el contrario, debido a la mayor concentración económica en torno a los ingenios, cuyos propietarios también lo eran de grandes fundos y mantenían bajo un régimen de patronazgo político extensas comarcas, el sistema de la papeleta tornábase más viable.

De todos modos, no era lo suficientemente sólido como para resistir la irrupción de un nuevo actor en el conflicto, el Estado nacional. Pero es necesario precisar que la oficina de "enganche" del ejército solo agudizó en Tucumán una crisis latente a partir de una situación que ya preexistía y que igualmente estaba en la base de la crisis del régimen de la papeleta en Mendoza (en donde también el Estado nacional horadó la institución con la presencia del Ferrocarril Andino): la manifiesta impotencia de los patrones y del Estado provincial para evitar que los trabajadores incumplieran sus contratos y que se fugaran dejando impagas las deudas por anticipos de salarios. En otras palabras, el conflicto en nueva escala que se desató en la provincia norteña con la irrupción en escena del ejército nacional y la campaña de la prensa de Buenos Aires contra de la ley de conchabos no hubiera sido posible de no mediar las estrategias "preconcebidas" y "premeditadas" de los trabajadores (así las calificaban los defensores del sistema), su pertinaz amor a la libertad y la decisión con la que enfrentaban a los patrones que reclamaban "derechos" sobre ellos al amparo de las disposiciones del conchabo obligatorio.

Como en el contexto latinoamericano, para una mejor aproximación al mundo del trabajo de las dos provincias argentinas mediterráneas en la segunda mitad del siglo XIX, no puede dejar de considerarse el rol central que les cupo como actores históricos a "los de abajo". 